\title{
MINERAL RESOURCE POTENTIAL OF THE LINVILLE GORGE WILDERNESS AND PROPOSED EXTENSIONS, BURKE AND MCDOWELL COUNTIES, NORTH CAROLINA
}

\author{
By \\ John P. D'Agostino and Jesse W. Whitlow, U.S. Geological Survey \\ and \\ Gertrude C. Gazdik and Donald K. Harrison, U.S. Bureau of Mines \\ 1983
}

Studies Related To Wilderness

Under the provisions of the Wilderness Act (Public Law 88-577, September 3, 1964) and related acts, the U.S. Geological Survey and the U.S. Bureau of Mines have been conducting mineral surveys of wilderness and primitive areas. Areas officially designated as "wilderness," "wild," or "canoe" when the act was passed were incorporated into the National Wilderness Preservation System, and some of them are presently being studied. The act provided that areas under consideration for wilderness designation should be studied for suitability for incorporation into the Wilderness System. The mineral surveys constitute one aspect of the suitability studies. The act directs that the results of such surveys are to be made available to the public and be submitted to the President and the Congress. This report presents the results of a mineral resource survey of the Linville Gorge Wilderness and proposed extensions in the Pisgah National Forest, Burke and McDowell Counties, N.C. Linville Gorge Wilderness was established by Public Law 88-577, September 3, 1964; Linville Gorge Extensions, northern part (A8058) and southern part (L8-058), are roadless areas classified as proposed wilderness during the Second Roadless Area Review and Evaluation (RARE II) by the U.S. Forest Service, January 1979.

\section{MINERAL RESOURCE POTENTIAL SUMMARY STATEMENT}

The mineral resource potential of the Linville Gorge Wilderness and proposed extensions is low. Silica sand is present in the Chilhowee Group but the quality is marginal for glassmaking and the sources are small. Rock suitable for small-size building stone and for crushed aggregate for construction use is abundant, but similar material is more readily accessible elsewhere. Sand and gravel in small amounts are available from alluvial deposits but access to them would be difficult. Significant concentrations of uranium in the Wilson Creek Gneiss are possible but none are known or indicated. Recent seismic data indicate that the Proterozoic and Cambrian metamorphic rocks exposed at the surface are 8,000 to $10,000 \mathrm{ft}$ thick and conceal Paleozoic sedimentary rocks 15,000 to $20,000 \mathrm{ft}$ thick that have an unknown potential for gaseous hydrocarbons and metallic-sulfide ores.

\section{INTRODUCTION}

The Linville Gorge Wilderness and proposed extensions contain 10,976 acres of Pisgah National Forest land in the Blue Ridge Mountains of western North Carolina. The original wilderness consists of 7,575 acres; the northern extension (A8-058) contains 876 acres and the southern extension (L8-058), 2,525 acres. The study area of combined wilderness and proposed extensions is almost entirely within Burke County; a small portion is in McDowell County (fig. 1). The area is $\mathbf{1 1} \mathrm{mi}$ north-northeast of Marion and $\mathbf{1 3}$ mi west-northwest of Morganton.

Several roads provide access to the study area (fig. 1). The western part can be reached by taking State Route (S.R.) 183 south from Linville Falls to Kistler Memorial Highway, a gravel road that is the western boundary of the study area. From this road several good foot trails lead into the gorge to the Linville River Trail along the west bank. From the Kistler Highway, Forest Service (F.S.) gravel route 117 can be taken to meet the Linville River Trail in the southern part of the area. The eastern part of the gorge can be approached by taking S.R. 181 to F.S. $210,0.5 \mathrm{mi}$ west of Cold Springs. F.S. 210 is a gravel road paralleling the northeastern boundary in the vicinity of Tablerock Mountain. Tablerock Mountain is also accessible from the southeast by gravel road F.S. 99. Two foot trails lead into the gorge from the east rim, terminating at the river. There is no trail along the east side of the Linville River, and fording the river is extremely hazardous. The southeastern part of the area is accessible by gravel road F.S. 117. From the end of F.S. 117 an eroded timber trail extends north along the crest of Shortoff Mountain to Tablerock Mountain.

The area is heavily forested with mixed hardwoods and softwoods. A dense understory of rhododendron and laurel makes off-trail hiking very difficult. Cliffs, as much as $900 \mathrm{ft}$ high and several thousand feet long, occur throughout the gorge area and form most of the gorge rim. They create spectacular scenery but also restrict access. Altitudes range from $1,240 \mathrm{ft}$ at river level on the southern boundary to $4,120 \mathrm{ft}$ at the top of Gingercake Mountain on the northeastern boundary, resulting in maximum relief of nearly $2,900 \mathrm{ft}$. 
$81^{\circ} 45^{\prime}$

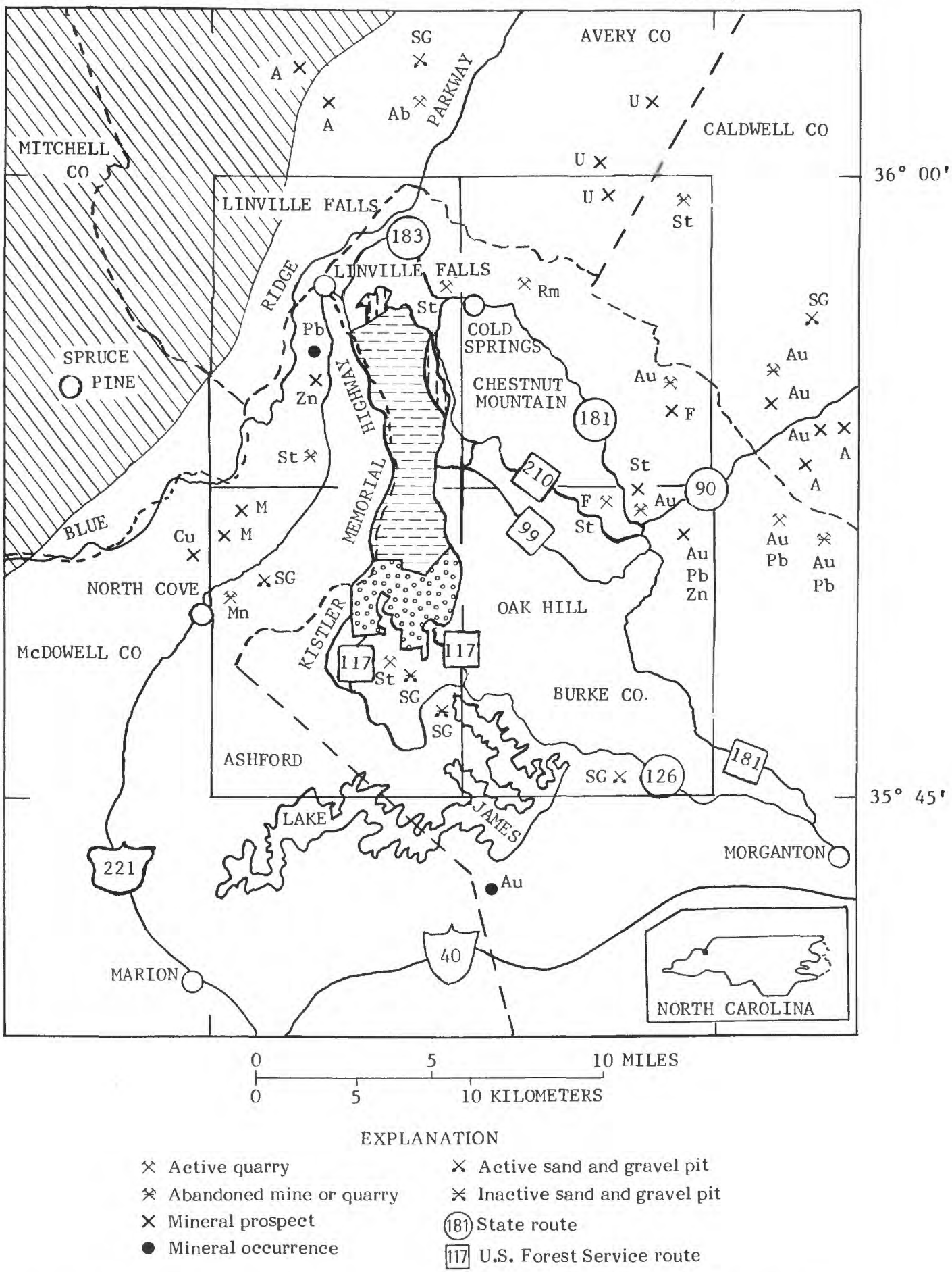

Figure 1.--Index map showing location of the Linville Gorge Wilderness (horizontal stippling), proposed extensions (A8-058, northern part, vertical stippling; and L8-058, southern part, circles), and Spruce Pine mining district (slanted stripes). Outlines and names of U.S. Geological Survey 7 1/2-minute topographic quadrangles are shown. Letter designations: A, asbestos; $\mathrm{Ab}$, abrasives (garnet); $\mathrm{Au}$, gold; $\mathrm{Cu}$, copper; $\mathrm{F}$, fluorite; $\mathrm{M}$, mica; $\mathrm{Mn}$, manganese; $\mathrm{Pb}$, lead; $\mathrm{Rm}$, road metal; $\mathrm{SG}$, sand and gravel; St, building stone; U, uranium; and $\mathrm{Zn}$, zinc. Sources are chiefly Reed (1964) and Bryant and Reed (1966). 
Linville River, the main drainage, flows south into Lake James, a reservoir on the Catawba River. The gorge is in the middle course of the Linville River and is one of the deeper dissections on the edge of the Blue Ridge. Small, short tributaries of the Linville River drain the slopes of the wilderness. More streams are perennial on the eastern gorge wall than on the western wall.

\section{Previous Investigations}

An early reconnaissance geologic map that includes the Linville Gorge area was prepared for the 30-minute Morganton quadrangie by Keith and Sterrett (1954). Bryant and Reed made a detailed study of the geology and structure of the Grandfather Mountain window, which includes Linville Gorge, between 1956 and 1962 (Bryant and Reed, 1966; 1970). Of specific interest are the geologic map of the 15-minute Linville Falls quadrangle (Reed, 1964) and a mineral resource survey (Bryant and Reed, 1966). Short regional reports that include data on the study area have been published on structure (Jonas, 1932; King, 1955), on metamorphism (Kulp and Poldervaart, 1956), on metamorphism and geologic dating (Long, Kulp, and Eckelmann, 1959), and on petrology (Eckelmann and Kulp, 1956). A directory, with maps, of active North Carolina mineral producers, some of which are in the vicinity of the wilderness, has been compiled by McDaniel and McKenzie (1976). Maps of geochemical and radioactivity surveys of the Charlotte $2^{\circ}$ quadrangle, which includes the wilderness, have been published by Heffner and Ferguson (1978).

\section{Present Investigations}

D'Agostino and Whitlow, U.S. Geological Survey (USGS), sampled the Linville Gorge Wilderness in October 1977 and the proposed extensions in April 1979. They collected 132 samples; 32 are rock chip, 42 are soil, and 58 are bulk stream-sediment. David $F$. Siems of the Denver laboratories of the USGS analyzed the samples for 31 elements using the semiquantitative emission spectrographic six-step direct-current-arc method. These results are shown in the goechemical report by D'Agostino and others (in press).

Gazdik and Harrison of the U.S. Bureau of Mines (USBM) sampled the wilderness proper in the fall of 1978 , and, aided by Michael P. Davis, sampled the proposed extensions in the spring of 1980. Thirty-one random or continuous chip samples of rock outcrops were taken. Spectrographic analyses for 40 elements were done at the U.S. Bureau of Mines, Reno Research Center, Reno, Nev., where some samples were additionally tested for silica, uranium, and thorium.

\section{Acknowledgments}

The authors wish to thank for their assistance the staff of the U.S. Forest Service, Pisgah National Forest, Grandfather Mountain District, Marion, N.C. Special thanks are extended to District Rangers John Kennedy for providing details of the Linville River and wilderness trails and George $\mathrm{H}$. Cook for his aid on the proposed extensions. Appreciation is also extended to Joseph Moore, U.S. Forest Service, Asheville, N.C., for providing information on prospecting permits near the wilderness, and to William Stewart, U.S. Forest Service Regional Office, Atlanta, Ga., for providing land-status and mineral ownership maps.

\section{SURFACE-AND MINERAL-RIGHTS OWNERSHIP}

The U.S. Government owns all of the surface rights and about 96 percent of the mineral rights in the wilderness and proposed extensions. Figure 2 shows the areas of mineral rights held in perpetuity by private parties. Although prospecting and mining development permits are granted in Pisgah National Forest, there is no record of any permit application nor any historical account of prospecting or mining in what is now the Linville Gorge Wilderness and proposed extensions.

\section{GEOLOGY}

The Linville Gorge Wilderness and part of the proposed extensions are mostly within a geologically unique feature--the Grandfather Mountain window (Bryant and Reed, 1970). This geologic window is an area in which erosion through several thrust sheets has exposed underlying rocks of different and in part younger ages. All of the rocks exposed in the study area show strong evidence of deformation and have been moved to their present site from an original location tens of miles to the east. There are at least three exposed thrust sheets (Harris and others, 1981). The unnamed lowest sheet contains the Middle Proterozoic Wilson Creek Gneiss and the overlying Late Proterozoic Grandfather Mountain Formation (Reed, 1964). Above this is the Tablerock thrust sheet, which contains the Late Proterozoic and Early Cambrian Chilhowee Group (Reed, 1964). Overlying this and forming the "frame" of the window is the Blue Ridge thrust sheet, the uppermost thrust sheet, and it contains the Middle Proterozoic Cranberry Gneiss.

The Middle Proterozoic Wilson Creek Gneiss is the oldest bedrock outcropping in the wilderness, and it is exposed in the southwestern part of the Grandfather Mountain window along the gorge of the Linville River (fig. 3). The rock is a massive and layered, light-gray to greenish-gray, medium- to coarse-grained, cataclastic granitic gneiss. A thickness of about 800 to $1,600 \mathrm{ft}$ crops out along the eastern gorge wall and about 350 to $1,200 \mathrm{ft}$ is exposed along the western wall.

The Late Proterozoic Grandfather Mountain Formation unconformably overlies the Wilson Creek Gneiss. It consists of four members but only two occur in the study area. The first is a basal sericitic arkose, which comprises fine- to coarse-grained, thin to massive beds of green, tan, or gray. It crops out in the north-central part of the study area, in the vicinity of Hawksbill Mountain on the eastern side of the gorge and at Wisemans View and Laurel Knob on the western side. The arkose has an exposed thickness of about $1,860 \mathrm{ft}$ at Hawksbill Mountain and about $800 \mathrm{ft}$ at Wisemans View and Laurel Knob.

Overlying the arkose is the second member of the Grandfather Mountain Formation occurring in the study area, a fine-grained, mostly dark, thinly laminated siltstone, phyllite, and phyllitic schist. It is commonly calcareous and contains massive beds of graywacke and graywacke conglomerate. This member occurs in the northeastern part of the study area as a narrow outcrop zone trending west and north of Sitting Bear Mountain. Its thickness is about 50 to $250 \mathrm{ft}$.

Overlying the lowest unnamed thrust sheet is the Tablerock thrust sheet, which contains the Late Proterozoic and Early Cambrian Chilhowee Group 


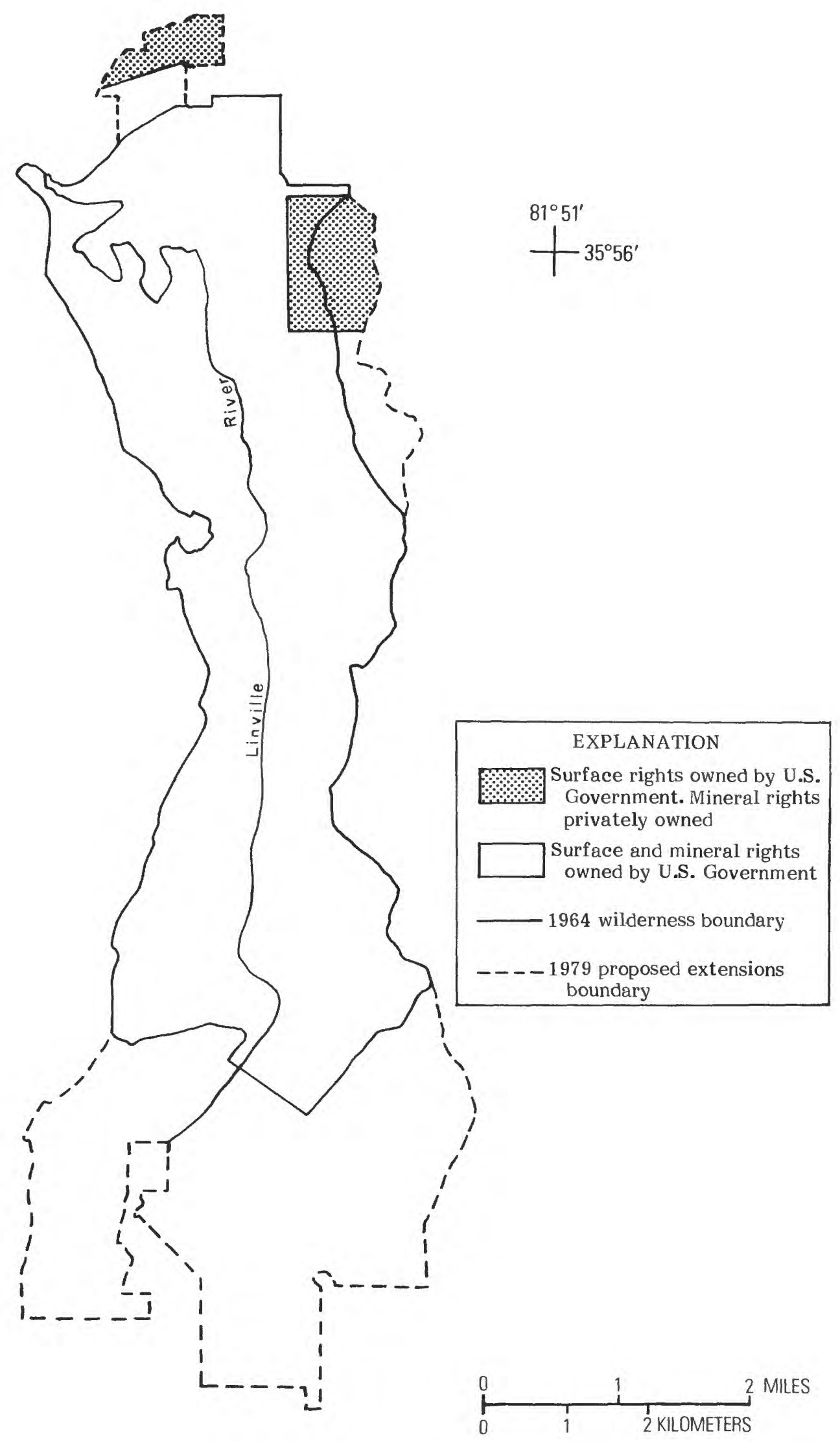

Figure 2.--Status of surface- and mineral-rights ownership in the Linville Gorge Wilderness and proposed extensions. 


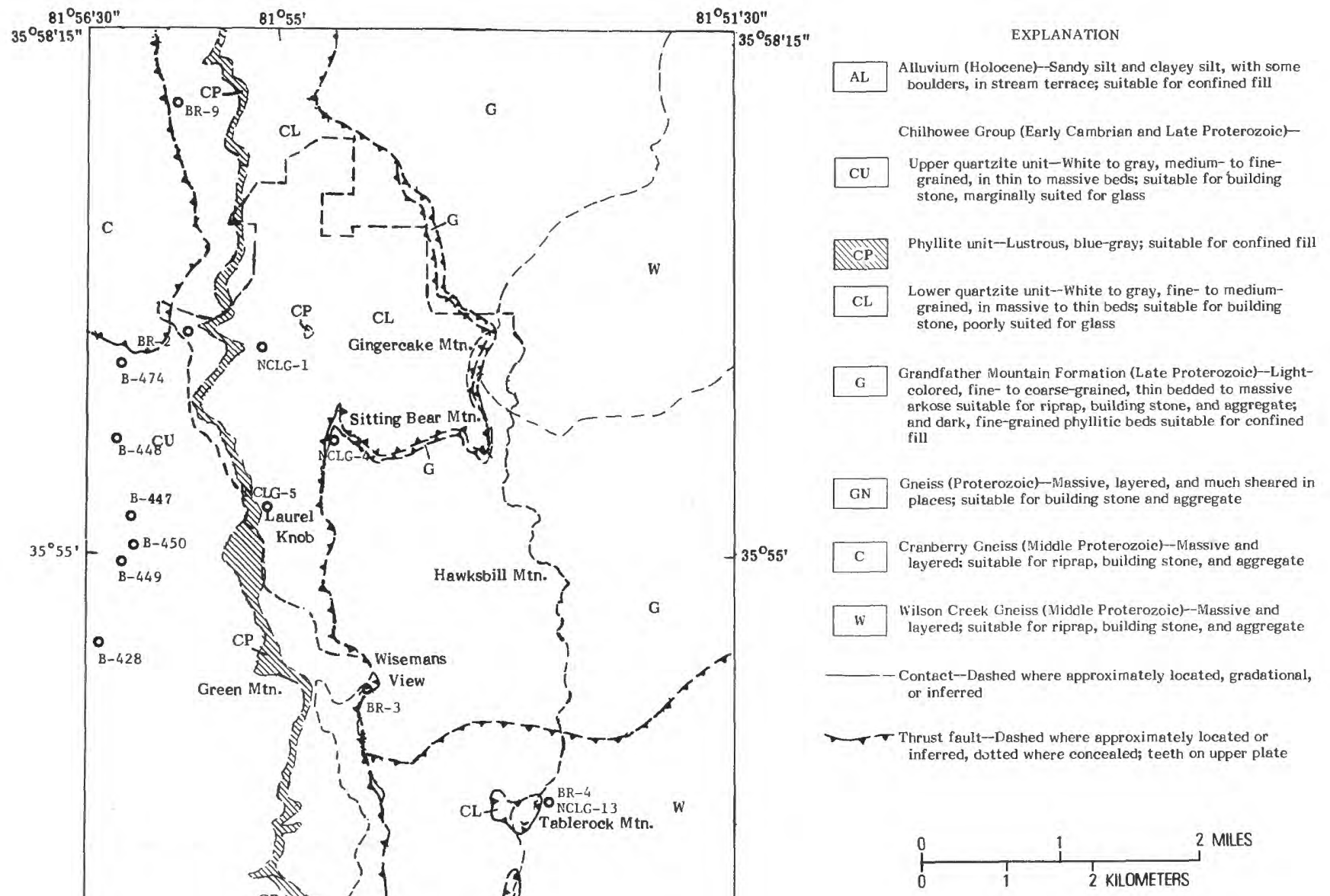


(Reed, 1964). The Chilhowee is subdivided into three units, the lower quartzite, middle phyllite, and upper quartzite. The lower quartzite unit consists of massive to thin beds of medium- to fine-grained, white to gray quartzite. It crops out throughout the northern, western, and southeastern parts of the study area, and also forms the klippen or erosional remnants capping Tablerock Mountain and The Chimneys. The unit is 244 to about $1,600 \mathrm{ft}$ thick in the study area. The middle unit is a lustrous blue-gray phyllite that has a thickness of a few feet to about $100 \mathrm{ft}$ where it crops out along the western boundary of the study area, and a thickness of as much as $450 \mathrm{ft}$ where it crops out in the gorge in the northern part of the study area. The upper quartzite unit consists of thin to massive beds of medium- to fine-grained, white to gray quartzite. Along the western boundary of the study area it is about $200 \mathrm{ft}$ thick, and in the gorge in the northern part it is about $480 \mathrm{ft}$ thick.

The Blue Ridge thrust sheet, which overlies the two lower thrust sheets (Reed, 1964), is present in a small area in the extreme northwestern corner of the study area. Of the many rock units contained in the Blue Ridge sheet, only the Middle Proterozoic Cranberry Gneiss occurs within the study area. Where exposed outside the study area it consists of lightcolored granitic gneisses interlayered with dark biotite gneiss and biotite schist. The unit reportedly is similar in age to the Wilson Creek Gneiss.

A small area of poorly exposed Proterozoic gneiss occurs in the southernmost part of the proposed extensions. Exposures of the Proterozoic gneiss east and south of the wilderness are described by Reed (1964) as a strongly sheared fine- to medium-grained layered rock commonly containing pods of amphibolite. Locally there are numerous bodies of pegmatite less than $1 \mathrm{ft}$ thick.

The total thickness of the three thrust sheets with rocks of Middle Proterozoic to Early Cambrian age is about 8,000 to $10,000 \mathrm{ft}$ (Cook and others, 1979; Harris and others, 1981). They overlie and conceal a younger Paleozoic sequence of unmetamorphosed sedimentary strata $\mathbf{1 5 , 0 0 0}$ to $20,000 \mathrm{ft}$ thick. Part of this sequence underlying the wilderness at depth was horizontally moved dozens of miles from the east (Harris and others, 1981).

\section{GEOCHEMICAL SURVEY}

A reconnaissance geochemical survey of the wilderness and proposed extensions found no evidence for the occurrence of metallic mineral resources. The samples collected include 32 rock, 58 streamsediment, and 42 soil that were analyzed for 31 elements by means of semiquantitative emission spectrographic analysis methods in the Denver laboratories of the USGS (D'Agostino and others, in press). In general the samples contain much less than the usual or normal range of metal concentrations except for boron, barium, and zirconium, which are a small increment above the normal range for similar rocks in the eastern United States (table 1). The data also show stream sediments and soils that may have about double the amount of copper and lead and onethird the amount of barium as underlying bedrock. The copper and lead concentrations, however, are still trace amounts and are insignificant. Results of the geochemical survey indicate a low potential for metallic deposits in the wilderness and proposed extensions.

\section{ASSESSMENT OF MINERAL RESOURCE POTENTIAL}

The known mineral resources in the Linville Gorge Wilderness and proposed extensions are limited to stone suitable for construction materials, quartzite suitable for low-quality glass sand, and small amounts of sand and gravel. All of these materials are available outside the study area.

Recent geophysical data indicate that Paleozoic sedimentary rocks 15,000 to $20,000 \mathrm{ft}$ thick are covered by 8,000 to $10,000 \mathrm{ft}$ of Middle Proterozoic to Cambrian igneous and metamorphic rocks (Cook and others, 1979; Harris and others, 1981). The areas underlain by the sedimentary rock have an unknown potential for gaseous hydrocarbons and metallicsulfide ores which can be tested only by drilling.

There has been no mineral production in the study area, although mining has occurred nearby (fig. 1). Beginning $3 \mathrm{mi}$ west of the wilderness is the very large Spruce Pine district which for more than 100 years has been a major producer of mica, feldspar, quartz, and clay (Lesure, 1968), but none of the rocks containing these resources are present in the study area. Other commodities that have been mined or identified as present near the wilderness are asbestos, abrasives (garnet), gold, copper, fluorite, mica, manganese, lead, uranium, and zinc, and rock quarries and sand-and-gravel pits (Bryant and Reed, 1966; Reed, 1964; and Conrad, 1960). Except for uranium and construction materials, these metals and minerals are found in rock types that do not occur in the study area. Analyses of rock, soil, and stream-sediment samples and field inspection of exposed rock layers did not reveal anomalous amounts of these metals and minerals in the study area.

Geochemical studies of the Wilson Creek Gneiss in the Lost Cove and Harper Creek Roadless Areas in Avery and Caldwell Counties, N.C., about $8 \mathrm{mi}$ eastnortheast of the town of Linville Falls, have outlined areas having a potential for uranium (Crandall and others, 1982). The uranium minerals are in phyllonitic zones: either as layers in fresh bedrock or as concentrations in surface oxidation zones (Bryant and Reed, 1966; U.S. Department of Energy, 1979). USGS and USBM personnel separately traversed areas of similar rock in the Linville Gorge Wilderness and proposed extensions using scintillation counters to measure radioactivity, but neither party found significantly anomalous radiation that might indicate bedrock that could be a source of uranium-ore minerals. Samples slightly more radioactive than background levels, which were collected from the southern edge of the southernmost Linville Gorge Extension, contain disseminated grains of the thorium mineral thorite which in turn contains minute amounts of uranium (Gazdik and Harrison, 1981, p. 26). The analytical and field studies suggest that the wilderness and extensions have low potential for uranium resources.

\section{Silica sand}

Chemical analyses indicate that the two prominent units of massive quartzite of the Late Proterozoic and Early Cambrian Chilhowee Group are not of sufficient purity in the study area to have any major potential use as glass sand except for making the lowest quality colored glasses and window glass (Broadhurst, 1949; Bryant and Reed, 1970, table 18); 
Table 1.--Range and average concentrations of elements detected for all samples collected by the U.S. Geological Survey in the study area

[Analyzed by David F. Siems, USGS, by means of semiquantitative emission spectrographic sixstep direct-current-arc method. $\mathrm{Fe}, \mathrm{Mg}, \mathrm{Ca}$, and $\mathrm{Ti}$ reported in percent (\%); all other elements reported in parts per million (ppm); lower limits of determination are in parentheses; G, greater than value shown; $\mathrm{N}$, not detected at limit of determination or at value shown; $\mathrm{L}$, detected, but below limit of determination, or below value shown. Following elements analyzed for but not detected, with limit of detection (ppm) in parentheses: $\mathrm{As}(200), \mathrm{Au}(10), \mathrm{Bi}(10), \mathrm{Cd}(20), \mathrm{Sb}(100)$, $\mathrm{W}(50)$, and $\mathrm{Zn}(200)]$

Element

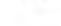

$$
\begin{gathered}
\text { Stream sediments } \\
58 \text { samples }
\end{gathered}
$$

high

low average

0.3

2.36

0.07

0.29

L

0.13

0.1

0.5

15

2000

$$
\text { N }
$$

500

700

10

100

100

50

200

N

20

70

100

20

10

200

L

100

100

G 1000

\section{N N}

10

72

200

420

2.7

N

10

\section{L}

20

14

28

12

56

\section{N}

L

N

5

22

$5 \quad 36$

L 8

N N

L N

N N

$10 \quad 73$

10

32

150

532

N N

Soils

42 samples

high low average

$\begin{array}{lll}5 & 1.5 & 2.4\end{array}$

0.7

0.07

0.25

0.07 L

$0.7 \quad 0.15$

L

0.41

$\begin{array}{lll}500 \quad 15 & 135\end{array}$

$\begin{array}{lll}\text { N } & \text { N }\end{array}$

$\begin{array}{lll}200 \quad 10 & 70\end{array}$

$700 \quad 150 \quad 336$

$\begin{array}{lll}5 & 1 & 1.9\end{array}$

20

100

L

6.5

$10 \quad 26$

$\begin{array}{lll}50 & \text { L }\end{array}$

$\begin{array}{lll}100 \quad 30 & 54\end{array}$

10

10

L

L

10

70

100

$$
15
$$

N

N

L

13

28

$10 \quad 28$

58

N N

100

L L

N N N

$\begin{array}{lll}150 & 30 \quad 56\end{array}$

$\begin{array}{lll}100 & 10 \quad 28\end{array}$

$100 \quad 10 \quad 28$

$1,000 \quad 100 \quad 396$ 
however, this does not consider the practicality of lowering impurities by beneficiation. The lower quartzite unit is exposed extensively throughout the wilderness but analytical data show that the untreated quartzite does not even meet the requirements for 9 th-quality amber glass (table 2). The upper quartzite unit is restricted by the wilderness boundary to two narrow mile-long strips paralleling the crest of Linville Mountain and to an isolated faulted sliver in the southeast corner. Tests reveal that this unit has only moderately high silica for glassmaking (table 2), and that alumina and iron content are low enough to permit its use as 7th-quality green or 9th-quality amber glass. Figure 3 shows the localities of samples having 90 percent or more silica taken from the lower and upper quartzite units of the Chilhowee Group. Supplies of silica sand of similar and better quality are abundant outside the wilderness and proposed extensions.

\section{Construction materials}

There are no rock quarries or sand and gravel pits in the study area. The bedrock is satisfactory for use as building stone in small structures but would be poorly suited for multi-storied structures. The rocks mostly are strongly foliated, which causes them to have a low bearing strength and load capacity parallel to the foliation. Bedrock where slabby could be used for decorative dressing or facing stone where bearing strength is unimportant. The presence of soft, weak minerals in most of the bedrock would be deleterious in aggregate used for concrete because they reduce the strength of the concrete, and, upon weathering, quicken its disintegration. The crushed stone would be suitable as a wearing surface for roads. Crushed soft rock such as the phyllite could be used for fill if confined.

Sand and gravel in limited amounts could be obtained along the gorge bottom from small irregularly spaced alluvial fans composed of silt- to cobble-size material (Reed, 1964). Screening and washing of the fan debris would probably be necessary before use.

Deposits of construction materials within the wilderness and proposed extensions are located mostly away from roads, which would mean an added cost for quarry and pit development, but similar rocks, and different rocks of higher quality better suited for quarrying, occur adjacent to roads outside the study area boundary (Councill, 1955; McDaniel and McKenzie, 1976). Considerable amounts of sand and gravel are available on the flood plain of the Linville River about $1 \mathrm{mi}$ south of the study area boundary, at the sites of inactive sand and gravel pits (fig. 1).

\section{REFERENCES CITED}

Broadhurst, S. D., 1949, A general survey of some high silica materials in North Carolina: North Carolina Department of Conservation, Division of Mineral Resources Information Circular 7, 30 p.

Bryant, Bruce, and Reed, J.C., Jr., 1966, Mineral resources of the Grandfather Mountain window and vicinity, North Carolina: U.S. Geological Survey Circular 521, 13 p.

1970, Geology of the Grandfather Mountain window and vicinity, North Carolina and Tennessee: U.S. Geological Survey Professional Paper 615, 190 p.
Conrad, S. G., 1960, Crystalline limestones of the Piedmont and mountain regions of North Carolina: North Carolina Department of Conservation and Development, Division of Mineral Resources Bulletin 74, 56 p.

Cook, F. A., Albaugh, D. S., Brown, L. D., Kaufman, Sidney, Oliver, J. E., and Hatcher, R. D., Jr., 1979, Thin-skinned tectonies in the crystalline southern Appalachians; COCORP seismicreflection profiling of the Blue Ridge and Piedmont: Geology, v. 7, no. 12, p. 563-567.

Councill, R. J., 1955, Petrography and economic aspects of the miscellaneous commercial rocks of North Carolina: North Carolina Department of Conservation and Development, Division of Mineral Resources Information Circular 13, 26 p.

Crandall, T. M., Ross, R. B., Jr., Whitlow, J. W., and Griffitts, W. R., 1982, Mineral resource potential map of the Lost Cove and Harper Creek Roadless Areas, Avery and Caldwell Counties, North Carolina: U.S. Geological Survey Miscellaneous Field Studies Map MF-1391-A.

D'Agostino, J. P., Whitlow, J. W., and Siems, D. F., in press, Geologic and geochemical maps of the Linville Gorge Wilderness and proposed extensions, Burke and McDowell Counties, North Carolina: U.S. Geological Survey Miscellaneous Field Studies Map MF-1610-A.

Eckelmann, F. D., and Kulp, J. L., 1956, The sedimentary origin and stratigraphic equivalence of the so-called Cranberry and Henderson granites in western North Carolina: American Journal of Science, v. 254, p. 288-315.

Gazdik, G. C., and Harrison, D. K., 1981, Mineral resources of the Linville Gorge Wilderness and additions, Burke and McDowell Counties, North Carolina: U.S. Bureau of Mines Open-File report MLA 16-81, 34 p.

Harris, L. D., Harris, A. G., de Witt, Wallace, Jr., and Bayer, K. C., 1981, Evaluation of southern eastern overthrust belt beneath Blue RidgePiedmont thrust: American Association of Petroleum Geologists Bulletin v. 65, no. 12, p. 2497-2505.

Heffner, J. D., and Ferguson, R. B., 1978, Preliminary raw data release, Charlotte $1^{\circ} \times 2^{\circ}$ NTMS area, North Carolina and South Carolina; National uranium resource evaluation program, hydrogeochemical and stream sediment reconnaissance: E.I. du Pont de Nemours and Co., Savannah River Laboratory, text 21 p., Appendix A, 12 p.; Appendix B, 107 p.; Appendix $\mathrm{C}, 27 \mathrm{p}$.

Jonas, A. I., 1932, Structure of the metamorphic belt of the southern Appalachians: American Journal of Science, 5 th Series, v. 24 , p. 228-243.

Keith, Arthur, and Sterrett, D. B., 1954, Geologic map of the Morganton quadrangle, North Carolina: U.S. Geological Survey Open-file report, scale $1: 125,000$.

King, P. B., 1955, A geologic section across the southern Appalachians-an outline of the geology in the segment in Tennessee, North Carolina, and South Carolina, in Russell, R. J., ed., Guides to southeastern geology: Geological Society of America Guidebook, p. 332-373.

Kulp, J. L., and Poldervaart, Arie, 1956, The metamorphic history of the Spruce Pine district: American Journal of Science, v. 254, no. 7, p. 393-403. 
Lesure, F. G., 1968, Mica deposits of the Blue Ridge in North Carolina: U.S. Geological Survey Professional Paper 577, 124 p.

Long, L. E., Kulp, J. L., and Eckelmann, F. D., 1959, Chronology of major metamorphic events in the southeastern United States: American Journal of Science, v. 257, no. 8, p. 585-603.

McDaniel, R. D., and McKenzie, B. J., 1976, Directory of North Carolina mineral producers: North
Carolina Department of Natural and Economic Resources, Division of Earth Resources, Mineral Resources Section, 64 p.

Reed, J. C., Jr., 1964, Geology of the Linville Falls quadrangle, North Carolina: U.S. Geological Survey Bulletin 1161-B, 53 p.

U.S. Department of Energy, 1979, National Uranium Resource Evaluation Interim Report, GJO 111(79), 137 p.

Table 2.--Silica, alumina, iron, and lime-magnesia content of Chilhowee Group samples having 90 percent or more $\mathrm{SiO}_{2}$

\begin{tabular}{|c|c|c|c|c|}
\hline & $\mathrm{SiO}_{2}$ & $\mathrm{Al}_{2} \mathrm{O}_{3}$ & $\mathrm{Fe}_{2} \mathrm{O}_{3}$ & $\mathrm{CaO}+\mathrm{MgO}$ \\
\hline Sample number ${ }^{1}$ & \multicolumn{4}{|c|}{ percent } \\
\hline
\end{tabular}

Upper quartzite unit

NCLG-5
$B-428$
$B-447$
$B-448$
$B-449$
$B-450$
$B-474$
$B R-9$

Lower quartzite unit

NCLG-4
NCLG-13
BR-2
BR-3
BR-4

$\begin{array}{rrrr}95.9 & 1.0 & 0.91 & --3 \\ 95.6 & 2.7 & .19 & -- \\ 91.0 & 7.2 & .17 & -- \\ 95.0 & 3.7 & .27 & -- \\ 95.4 & 3.6 & .12 & - \\ 94.9 & 4.1 & .16 & -- \\ 96.7 & 3.0 & .12 & - \\ 94.4 & 1.4 & 2.50 & 0.14\end{array}$

\footnotetext{
minimum

maximum

maximum

maximum

7 th quality, green glass ${ }^{2}$ 9 th quality, amber glass ${ }^{2}$

\section{0}

4.0

${ }^{1}$ Numbers preceded by:

NCLG - Samples collected by U.S. Bureau of Mines in 1978 and 1980 (Gazdik and Harrison, 1981, p. 30).

B - Analyses from Broadhurst, 1949 , p. 13, 14.

BR - Analyses from Bryant and Reed, 1970, p. 102.

${ }^{2}$ Specifications for chemical composition of glass sand recommended by American Ceramic Society and National Bureau of Standards.

3 -, not analyzed.
}

92.2

90.0

90.1

90.7

94.0

$\begin{array}{ll}-- & -- \\ -- & -- \\ .46 & .33 \\ .92 & .20 \\ .45 & .05\end{array}$


 